\title{
EFFECTS OF CERVICAL SYMPATHECTOMY ON VASOSPASM INDUCED BY MENINGEAL HAEMORRHAGE IN RABBITS
}

\author{
Antônio Tadeu de Souza Faleiros', Francisco Humberto de Abreu Maffei², \\ Luiz Antonio de Lima Resende ${ }^{3}$
}

\begin{abstract}
This study investigates the role of cervical sympathectomy in the prevention of acute vasospasm induced by meningeal haemorrhage in rabbits. Sixteen adult English Norfolk rabbits were divided into 2 experimental groups: bilateral cervical sympathectomy of the superior sympathetic ganglion (SSSG, $n=8$ ), and bilateral SSSG and sympathectomy of the inferior sympathetic ganglion (SISG, n=8). Other 24 animals were used as controls. Basilar artery diameter was evaluated by angiography. SSSG protected the animals against developing cerebral vasospasm; SSSG associated with SISG did not increase this effect.
\end{abstract}

KEY WORDS: subarachnoid haemorrhage, vasospasm, cervical sympathectomy .

\begin{abstract}
Efeitos da simpatectomia cervical sobre o vasoespasmo induzido por hemorragia meníngea em coelhos

RESUMO - Este estudo investiga o papel da simpatectomia cervical na prevenção do vasoespasmo agudo induzido por hemorragia meníngea em coelhos. Para tanto, foram utilizados 16 coelhos adultos da raça Norfolk inglesa, divididos em 2 grupos experimentais: simpatectomia cervical bilateral do gânglio simpático cervical superior (SSSG, $n=8$ ) e SSSG associada a simpatectomia cervical bilateral do gânglio simpático cenvical inferior (SISG, n=8). Outros 24 animais foram usados como controles. Os diâmetros das artérias basilares foram avaliados por medições após angiografias. SSSG protegeu os animais contra o vasoespasmo; SSSG associada a SISG não aumentou este efeito.
\end{abstract}

PALAVRAS-CHAVE: hemorragia subaracnóidea, vasoespasmo, simpatectomia.

The association between menigeal haemorrhage after aneurism rup tu re and localized constriction of cerebral blood vessels was described in man by Robertson, in 19491, although the first clear angiographic description of vasospasm under these conditions was made by Ecker and Riemenschneider in $1951^{2}$. Purkinje in 1836 and Remak in 1841, (quoted by White et al. ${ }^{3}$ ) discovered nerve fibres with the arteries of the Willis polygon. Penfield, in 1932, (quoted by White et al. ${ }^{3}$ ), showed sensitive afferent and efferent motor nerves in the adventitia and in the space between the adventitia and the muscle layer of all cerebral large and small arteries, and vein walls ${ }^{3}$.

Innenation of the human carotid vessels is supplied by the sympathetic system, originating mainly from the superior cervical ganglion, but also from the inferior ${ }^{4}$. Different methods have demonstrated p rofuse adrenergic innervation of the cerebral blood vessels ${ }^{5-10}$ and regulation of blood flow by the sympathetic system ${ }^{11,12}$. Functional ${ }^{13}$ and morphological ${ }^{14}$ alterations have been reported in cerebral arteries after cervical sympathectomy, but vasospasm pathogenesis after subarachnoid haemorrhage remain controversial.

The objective of this study is to investigate the effects of cervical sympathectomy on the development of vasospasm after subarachnoid haemorrhage induced in rabbits.

\section{METHOD}

Male and female 1,000 to 2,000 g adult English Norfolk rabbits were used; they were randomly distributed into 5 experimental groups:

Group $\mathrm{G1}$ - Sympathectomy controls ( $\mathrm{n}=8)$, submitted

${ }^{1}$ Services of Neurosurgery, ${ }^{2}$ Vascular Surgery and ${ }^{3}$ Neurology, Botucatu School of Medicine, São Paulo State University (UNESP), Botucatu, SP, Brazil.

Received 27 October 2005, received in final form 3 February 2006. Accepted 7 April 2006.

Dr. Luiz A.L. Resende - Department of Neurology and Psychiatry / Botucatu School of Medicine - 18618-000 Botucatu SP - Brasil. E-mail: luan_resende@uol.com.br 
to bilateral surgical manipulation of the superior cervical ganglion without ablation; after 6 weeks meningeal haemorrhage was simulated with suboccipital intrathecal $0.9 \%$ saline $0.15 \mathrm{~mL} / \mathrm{kg}$ injection into the magna cistern.

G roup G2 - Simulated sympathectomy with meningeal hae mo mage controls $(n=8)$, submitted to bilateral surgical manipulation of the superior cervical ganglion, without ablation; after 6 weeks they were submitted to meningeal haemorrhage by suboccipital intrathecal injection of $0.15 \mathrm{~mL} / \mathrm{kg}$ autologous blood into the magna cistern.

G roup G3 - Sympathectomy and meningeal haemorrhage $(n=8)$, submitted to bilateral gangliectomy of the superior cervical sympathetic ganglion; after 6 weeks they were submitted to meningeal haemorrhage by suboccipitally intrathecal injection of $0.15 \mathrm{~mL} / \mathrm{kg}$ autologous blood into the magna cistern.

G roup G4 - Simulated superior and inferior gangliectomy, and meningeal haemorrhage controls $(n=8)$, submitted to bilateral surgical manipulation of the superior and inferior cervical ganglion, without ablation; after 6 weeks they were submitted to meningeal haemorrhage by suboccipital intrathecal injection of $0.15 \mathrm{~mL} / \mathrm{kg}$ autologous blood into the magna cistern.

Group G5 - Superior and inferior sympathectomy and meningeal haemorrhage $(n=8)$, submitted to bilateral surgical gangliectomy of the superior and inferior cervical ganglion; after 6 weeks they were submitted to meningeal haem onhage by suboccipital intrathecal injection of 0.15 $\mathrm{mL} / \mathrm{kg}$ autologous blood into the magna cistern.

Histological examination - All gangliectomy specimens were sent to the Pathology Department, fixed in form o I, included in paraffin, and colored by hematoxilin-eosin, for histological confirmation of ganglionar tissue.

This study was perf o rmed in 2 phases; preparation of experimental groups, and analysis of angiographies.

Phase 1: Su rgical access to the cervical sympathetic ganglion, for manipulation or ablation, during general anaesthesia with $30 \mathrm{mg} / \mathrm{kg}$ tionembutal, administered endovenously in the ear dorsal vein, in spontaneous respiration with open mask adjusted to the muzzle with $2 \% \mathrm{O}_{2}$.

Phase 2: (6 weeks later) inhalatory anaesthesic was used to prevent cardiovascular disturbances and intracranial pressure variations. Induction: $1.5 \%$ isofluorane and $0.5 \% \mathrm{O}_{2}$ for 2 minutes; maintenance: $0.5 \%$ isofluorane and $0.5 \%$ $\mathrm{O}_{2}$, with anaesthetic apparatus with mask adjusted to the animal muzzle.

Autologous blood was obtained from the femoral artery. After subarachnoid haemorrhage or simulation, animals were maintained in $30^{\circ}$ Trendelenburg position to ensure full diffusion across the basilar artery.

Angiographies were obtained by injecting $0.2 \mathrm{~mL} / \mathrm{kg}$ Hexabrix 280 - Guerbet into the carotid artery via a catheter inserted after local anaesthesia with $0.5 \mathrm{~mL}$ xylocaine. Comparison between groups was by Analysis of Variance ${ }^{15}$ with
Table 1. Basilar artery diameter $(\mathrm{mm})$ for all groups, means with $S D$.

\begin{tabular}{ccc}
\hline Groups & Mean & Standard deviation \\
\hline G1 & 1.06 & 0.06 \\
G2 & 0.69 & 0.12 \\
G3 & 0.91 & 0.09 \\
G4 & 0.89 & 0.05 \\
G5 & 0.94 & 0.10 \\
\hline
\end{tabular}

Statistical analysis: $F=16.69 ; \mathrm{p}<0.001 ; \mathrm{G} 1>(\mathrm{G} 3=\mathrm{G} 4=\mathrm{G} 5)>\mathrm{G} 2$.

F and $p$-value determination. For $p<0.05$ cases, group means we re compared by the Tukey test using a minimum significant difference of $5 \%$.

\section{RESULTS}

Histological examinations of surgical specimens confirmed ganglion tissues in all cases.

Table 1 shows mean basilar art e rydiameters for all groups. There were significant statistical differences between groups.

G1 animals, with simulated bilateral gangliectomy and simulated meningeal haemorrhage, presented normal basilar arte ry diameter without demonstrable vasospasm.

G2 animals, with simulated gangliectomy and meningeal haemorrhage, presented the smallest basilar artery diameter, the highest vasospasm in all 5 groups.

There was no significant diff e rence between G3, 4 , and 5 animals in basilar artery diameter, but they we re significantly larger than G2, and smaller than G1 (Table 1). Thus, animals with superior cervical ganglion sympathectomy presented similar basilar artery diameter to animals with superior and inferior gangliectomy; vasospasms were minimal in these groups.

\section{DISCUSSION}

In this experiment, simulation of meningeal haemo rrhage with suboccipital intrathecal saline injection into the magna cistern did not produce vasospasm (G1). Animals with induced subarachnoid haemorrhage presented vasospasm (G2). Similar results have been reported ${ }^{14,16-22}$.

Bilateral extirpation of the sympathetic ganglion 6 weeks before subarachnoid haemorrhage (G3 and 5) prevented the development of acute vasospasm, demonstrating that the sympathetic system plays an important role in its pathogenesis. A similar effect was observed for animals with manipulation of the 
sympathetic ganglion and meningeal haemorrhage (G4); this is difficult to explain. Perhaps under the simulation conditions in G4, careful and delicate surgical manipulation of the sympathetic ganglion caused unintentional lesions in the sympathetic fibres. In a study performed in our laboratory, sympathectomy just before subarachnoid haemorrhage did not p roduce a protector effect for vasospasm development $^{23}$.

In rabbits, the basilar artery is the largest in the cerebral base, and its constriction is a normal response to stimulation of the sympathetic terminals.

The chronic bilateral cervical superior sympathectomy could provoke norepinephrine depletion in the small granular vesicles of the sympathetic terminals, impairing adre ne rgic transmission; this would then eliminate the constrictor sympathetic effect ${ }^{13}$. Our study is in agreement with published data where ph a rmacological or anatomical exclusion of the sympathetic activity prevented vasospasm ${ }^{24}$.

In conclusion, in this experimental model of subarachnoid haemorrhage in rabbits, and under the conditions that procedures were performed: 1) bilateral gangliectomy of the superior sympathetic ganglion performed 6 weeks before meningeal haemorrhage prevented development of acute vasospasm; 2) additional gangliectomy of the inferior sympathetic ganglion did not increase this effect.

\section{REFERENCES}

1. Robertson EG. Cerebral lesions due intracranial aneurysms. Brain 1949 72:100-185.

2. Ecker A, Riemenschneider PA. Arteriographic demonstration of spasm of the intracranial arteries with special reference to sacular arterial aneurysms. J Neurosurg 1951;8:660-667.

3. White RR, Hagen AA, Morgan H, Dawson WN, Robertson JT. Experimental study on the genesis of cerebral vasospasm. Stroke $1975 ; 6$ : $52-57$.
4. Lazorthes C. Vascularization et circulation cérébrales. Paris: Masson, 1961:163-172.

5. Falck B, Hillarp NA, Thieme G, Thorp A. Fluorescence of catecholamines and related compounds condensed with formaldeyde. J Histochem Cytochem 1962;10:438-454.

6. Falck B, Nielsen $\mathrm{KC}$, Owman $\mathrm{CH}$. Adrenergic innervation of the pial circulattion. Scand J Clin Lab Invest 1968;22(Suppl 102):VI-B.

7. Wurtman RJ. Catecholamines. N Engl J Med 1965;273:637-646,693-700, 746-753.

8. Sato S. An electron microscopic study on the innervation of the intracranial artery of the rat. Am J Anat 1966;118:873-880.

9. Nelson E, Rennels M. Innervation of intracranial arteries. Brain 1970;93: 475-490.

10. Nielsen $\mathrm{KC}$, Owman $\mathrm{CH}$, Sporrong B. Ultrastructure of the autonomic innervation apparatus in the main pial arteries of the rats and cats. Brain Res 1971;27:25-32.

11. Meyer JS, Yoshida K, Sakamoto K. Autonomic control of cerebral blood flow measured by electromagnetic flowmeters. Neurology 1967;17: 638-648.

12. James IM, Millar RA, Purves MJ. Observations on the extrinsic neural control of cerebral blood flow in the baboon. Circ Res 1969;25:77-93.

13. Lee TJF, Su C, Bevan JA. Neurogenic Sympathetic vasoconstriction of the rabbit basilar artery. Circ Res 1976;39:120-126.

14. Dimitriadu V, Aubineau P, Taxi J, Seylaz J. Ultrastructural changes in the cerebral artery wall induced by long-term sympathetic denervation. Blood Vessels 1988;25:122-143.

15. Zar JH. Biostatistical analysis. Englewood Cliffs: Prentice-Hall, 1984.

16. Waltz AG, Yamaguchi T, Regli F. Regulatory responses of cerebral vasculatureafter sympathetic denervation. Am J Physiol 1971;221:298-302.

17. Fraser RA, Stein BM, Barret RE. Noradrenergic mediation of experimental cerebrovascular spasm. Stroke 1970;1:356-362.

18. Peerless SJ, Yasargil MG. Adrenergic inervation of the cerebral blood vessels in the rabbit. J Neurosurg 1971;35:148-154.

19. Yoshioka S, Clower BR, Smith RR. The angiopathy of subarachnoid haemorrlage. I. Role of vessel wall catecholamines. Stroke 1988;15:228.

20. Tsukahara T, Taniguchi T, Fujiwara M, Handa J, Nishikawa M. Alterations in alfa adrenergic receptors in human cerebral artery after subarachnoid haemorrhage. Stroke 1985;16:53.

21. Alksne JF, Greenhoot JH. Experimental catecholamine induced chronic cerebral vasospasm: myonecrosis in vessel wall. J Neurosurg 1974;41: 440-445.

22. Delgado-Zygmunt TJ, Arbab MAR, Edvinsson L. Prevention of cerebral vasospasm in the rat by depletion or inhibition of substance $P$ in conduting vessels. J Neurosurg 1990;72:917-925.

23. Gabarra RC. Efeito da gangliectomia cervical superior bilateral e um inibidor do enzima conversor de angiotensina (captopril) no vasoespasmo precoce pós hemorragia meníngea. Estudo experimental em coelhos. Doctoral Thesis. Botucatu, 1991.

24. Bunc G, Kovacic S, Strnad S. Sympathetic nervous system exclusion following experimental subarachnoid haemorrhage prevents vasospasm in rabbits. Wien Klin Wochenschr 2000;112:533-539. 